\title{
Aplikasi Mading Digital Sebagai Media Promosi Produk Pelaku Usaha Mikro, Kecil Dan Menengah
}

\author{
Rio Jumardi ${ }^{*}$, Abadi Nugroho ${ }^{2}$ \\ ${ }^{1}$ Sekolah Tinggi Teknologi Bontang \\ Jl. Letjen S. Parman, No.65 Kel. Belimbing, Kota Bontang \\ Corresponding author's e-mail: jumardirio@gmail.com
}

\begin{abstract}
Abstrak - Kondisi pandemi covid-19 berdampak pada para pelaku UMKM dalam memasarkan produk dagangannya. Pelaku UMKM perlu beradaptasi dengan kondisi saat ini untuk memasarkan produknya. Pemilihan media promosi tepat harus diperhatikan dengan baik oleh pelaku UMKM agar secara efektif promosi produk tersampaikan kepada calon konsumen. Promosi UMKM berbasis digital dapat dilakukan dengan beberapa media, diantaranya media sosial atau media informasi berbasis web. Media digital berbasis web tersebut dapat dibuat berupa sebuah Mading Digital yang dapat diakses secara online oleh masyarakat menggunakan perangkat komputer maupun smartphone. Metode pengembangan sistem yang digunakan dalam penelitian ini adalah metode prototyping dengan langkah-langkah berupa pengumpula kebutuhan, perancangan, pengembangan prototipe dan pengujian sistem. Hasil dari penelitian menunjukkan bahwa Mading Digital berhasil dibuat sesuai dengan hasil perancangan dan kebutuhan sistem. Mading Digital yang telah dibuat dapat digunakan oleh pelaku UMKM sebagai media promosi serta dapat digunakan masyarakat untuk mencari produk UMKM yang dinginkan sekaligus melakukan pemesanan langsung kepada pemilik UMKM menggunakan perangkat yang mereka miliki.
\end{abstract}

Kata kunci: Digital, Mading, Promosi, UMKM, Website

Abstract- The COVID-19 pandemic has had an impact on SMEs in marketing their merchandise. MSME actors need to adapt to current conditions to market their products. The selection of the right promotional media must be carefully considered by MSME actors so that product promotion is effectively conveyed to potential consumers. Digital-based MSME promotions can be done with several media, including social media or web-based information media. Web-based digital media can be made in the form of a Digital Mading that can be accessed online by the public using computers or smartphones. The system development method used in this research is the prototyping method with the steps of collecting requirements, designing, developing prototypes and testing systems. The results of the study indicate that Mading Digital was successfully made in accordance with the results of the design and system requirements. The Digital Mading that has been made can be used by MSME actors as a promotional media and can be used by the public to find the MSME products they want while placing orders directly to MSME owners using the devices they have.

Keyword: Digital, Mading, Promotion, MSME, Website

\section{Pendahuluan}

Pandemi covid-19 telah melanda Indonesia kurang lebih dua tahun lamanya. Pemerintah dengan segala upaya melakukan pencegahan penyebaran virus covid-19 dengan melaksanakan kebijakan Pembatasan Sosial Berskala Besar (PSBB) sampai dengan kebijakan Pemberlakuan Pembatasan Kegiatan Masyarakat (PPKM) ditahun 2021. Namun kebijakan tersebut berdampak pada menurunnya aktifitas perekonomian nasional tidak terkecuali aktifitas pada sektor Usaha Mikro, Kecil dan Menengah (UMKM)[1]. Usaha Mikro, Kecil dan Menengah (UMKM) merupakan kelompok usaha baik dilakukan oleh individu maupun badan usaha untuk usaha kuliner, fashion maupun agribisnis. UMKM di Indonesia adalah sektor yang dapat menopang perekonomian bangsa dan dinilai sangat berpengaruh terhadap pemberian kesempatan kerja langsung kepada masyarakat sekitar[2].

Kondisi pandemi covid-19 berdampak pada para pelaku UMKM dalam memasarkan produk dagangannya. Pelaku UMKM perlu beradaptasi dengan kondisi saat ini untuk memasarkan produknya[3]. Pemilihan media promosi tepat harus diperhatikan dengan baik oleh pelaku UMKM agar secara efektif promosi produk tersapaikan kepada calon konsumen[4]. Media promosi pemasaran yang selama ini dilakukan oleh pelaku UMKM secara konvesional sudah harus berganti dan bertransformasi berbasis promosi digital. Strategi digitalisasi promosi produk UMKM berbasis online merupakan salah satu cara yang dapat digunakan UMKM untuk bertahan ditengah pandemi covid-19[5].

Promosi UMKM berbasis digital dapat dilakukan dengan beberapa media, diantaranya media sosial atau media informasi berbasis web. Sejauh ini, promosi UMKM dengan memanfaatkan platform digital sudah dilakukan melalui media sosial namun juga terkendala kurang efektifnya pencarian produk yang diinginkan. 
Selain memanfaatkan media sosial, media promosi berbasis web juga perlu dibuat sebagai sebuah wadah yang dapat menampung seluruh UMKM untuk memasarkan produk mereka secara terpusat. Media digital berbasis web tersebut dapat dibuat berupa sebuah Mading Digital yang dapat diakses secara online oleh masyarakat menggunakan perangkat komputer maupun smartphone[6].

Dengan adanya media berbasis Mading Digital tersebut produk-produk dari pelaku UMKM diharapkan dapat dipromosikan melalui satu pintu dan terpusat. Promosi yang dilakukan dapat memuat kemudahan informasi dan pemesanan produk sehingga dapat menarik masyarakat dalam mencari produk-produk UMKM, dapat meningkatkan pendapatan dari UMKM itu sendiri serta meningkatkan aktifitas dan kontribusi perekonomian di Indonesia. Penelitian ini bertujuan untuk membuat sebuah media online berbasis Mading Digital untuk membantu masyarakat sebagai pelaku UMKM untuk memasarkan produknya, maupun pada masyarakat sebagai konsumen dalam mencari produk UMKM yang dibutuhkan.

\section{Tinjauan Pustaka}

2.1. Aplikasi

Aplikasi merupakan program yang ditulis oleh program komputer untuk memecahkan suatu masalah tertentu dengan menggunakan bahasa pemrograman. Aplikasi adalah suatu suatu sub kelas perangkat lunak komputer yang memanfaatkan kemampuan komputer langsung untuk melakukan suatu tugas yang diinginkan pengguna. Biasanya dibandingkan dengan perangkat lunak sistem yang mengintegrasikan berbagai kemampuan komputer, tetapi tidak secara langsung menerapkan kemampuan tersebut untuk mengerjakan suatu tugas yang menguntungkan pengguna[7].

2.2. Basis Data

Basis data terdiri dari 2 kata, yaitu basis dan data. Basis dapat diartikan sebagai markas atau gudang, tempat bersarang atau berkumpul. Sedangkan Data adalah representasi fakta dunia nyata yang mewakili sutu obyek seperti manusia, barang, peristiwa, konsep, keadaan dan sebagainya. Basis data dapat didefinisikan dalam berbagai sudut pandang seperti[8]:

1. Himpunan kelompok data (arsip) yang saling berhubungan yang diorganisasikan sedemikian rupa agar kelak dapat dimanfaatkan kembali dengan cepat dan mudah.

2. Kumpulan data yang saling berhubungan yang disimpan secara bersama sedemikian rupa dan tanpa penanggulangan (redudansi) yang tidak perlu, untuk memenuhi berbagai kebutuhan.

3. Kumpulan file/tabel/arsip yang saling berhubungan yang disimpan dalam media penyimpanan elektronis.

Model Entity-Relationship berisi komponen-komponen Himpunan Entitas dan Himpunan Relasi yang masing-masing dilengkapi dengan atribut-atribut yang mempresentasikan seluruh fakta dari dunia nyata yang ditinjau dan dapat digambarkan dengan lebih sistematis dengan menggunakan Diagram Entity-Relationship[9]. Kardinalitas Relasi dapat dinyatakan dangan banyaknya garis cabang atau dengan pemakaian angka (1 dan 1 untuk relasi satu-ke-satu, 1 dan $\mathrm{N}$ untuk relasi satu-ke-banyak atau $\mathrm{N}$ dan $\mathrm{N}$ untuk relasi banyak-ke-banyak)[8].

\section{Metode Penelitian}

Metode pengembangan sistem yang digunakan dalam penelitian ini adalah metode prototyping. Metode prototyping menggambarkan model fisik dan kerangka kerja versi pertama dari sebuah sistem[10]. Langkahlangkah dalam metode prototyping terdiri dari[10]:

1. Pengumpulan kebutuhan

Pada tahap ini dilakukan pengumpulan kebutuhan sistem untuk mendeskripsikan kebutuhan dalam pengembangan perangkat lunak yang nantinya dibutuhkan oleh pengguna[11]. Kebutuhan perangkat lunak yang didokumentasikan pada tahap ini berkaitan dengan kebutuhan perangkat lunak dan kebutuhan perangkat keras. Pengumpulan kebutuhan sistem menentukan keseluruhan tujuan dibuatnya sistem tersebut[10].

2. Proses desain

Tahap ini focus pada representasi aspek perangkat lunak berupa input, proses dan output[10]. Tahap desain dalam pengembangan perangkat lunak berkaitan dengan pemodelan konseptual yang nantinya digunakan pada tahap pengembangan.

3. Membangun prototipe

Setelah pengumpulan kebutuhan dan desain model konseptual sudah dilakukan, tahap selanjutnya adalah membuat protipe aplikasi. Pembuatan prototipe disesuaikan dengan model konseptual yang dilakukan dengan mengacu pada kebutuhan perangkat lunak dan perangkat keras yang dibuat.

4. Evaluasi dan perbaikan 
Tahap evaluasi dan perbaikan merupakan tahap penting yang digunakan untuk menguji seberapai baik sistem berjalan dilingkungan aslinya. Metode pengujian yang digunakan adalah metode blackbox dengan functional testing sebagai jenis pengujiannya.

\section{Hasil dan Pembahasan}

Pengumpulan kebutuhan yang telah dilakukan dalam penelitian ini terdiri dari kebutuhan pengguna, kebutuhan input, kebutuhan output, kebutuhan perangkat lunak dan kebutuhan perangkat keras.

1. Kebutuhan pengguna

Pengguna Mading Digital terdiri dari:

1. Masyarakat sebagai pengguna yang berinteraksi langsung dengan Mading Digital. Masyarakat akan mendapatkan informasi mengenai event UMKM, pelaku UMKM, produk UMKM, serta dapat melakukan pemesanan yang terhubung langsung ke aplikasi messenger pemilik UMKM.

2. Admin sebagai pengguna yang mengolah seluruh data yang akan ditampilkan pada Mading Digital. Admin akan diberikan akses login untuk mengolah data event, pelaku dan produk UMKM serta admin mempunyai kewenangan untuk memberikan status ditampilkan/tidak ditampilkan suatu informasi di Mading Digital.

2. Kebutuhan Input

Kebutuhan data yang dibutuhkan dalam sistem ini adalah data pelaku UMKM, data produk UMKM, data event dan status tampilan. Proses input akan dilakukan oleh admin. Proses input

3. Kebutuhan Output

Informasi yang ditampilkan pada Mading Digital terdiri dari:
a. Informasi event UMKM;
b. Informasi pelaku UMKM;
c. Galeri produk UMKM dan
d. Informasi tambahan dalam bentuk teks berjalan.

4. Kebutuhan perangkat lunak

Perangkat lunak yang dibutuhkan dalam membangun Mading Digital ini terdiri dari Bahasa pemrograman, web server dan database. Bahasa pemrograman menggunakan paket web programming yang terdiri dari HTML, CSS, PHP dan Javascript. Webserver menggunakan apache dan database menggunakan Mysql.

5. Kebutuhan perangkat keras

Untuk mewujudkan Mading Digital juga dibutuhkan perangkat keras berupa seperangkat personal komputer dengan spesifikasi minimum menggunakan kecepatan prosesor $1 \mathrm{Ghz}$, RAM 4GB serta kapasitas penyimpanan berupa SSD 120 GB.

6. Arsitektur Sistem

Arsitektur sistem digunakan untuk menggambarkan kebutuhan teknis dari sistem yang akan dibangun. Arsitektur sistem dalam Mading Digital ini dapat dilihat pada gambar 1.

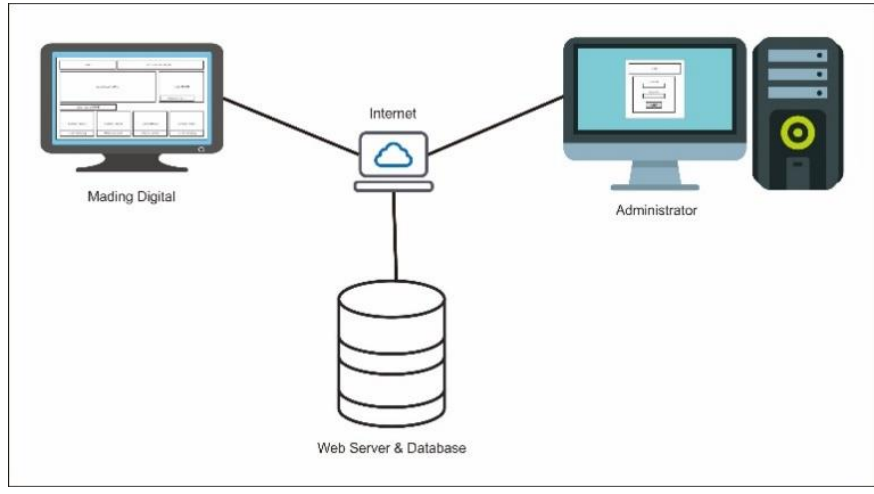

Gambar 1. Arsitektur Sistem

Setelah dilakukan pengumpulan kebutuhan, selanjutnya dilakukan perancangan dari sistem yang akan dibangun. Perancangan yang dilakukan pada tahap ini adalah membuat model konseptual terhadap sistem yang akan dibangun. Model konseptual yang dibangun menggunakan Unified Modeling Language (UML). Adapun model-model konseptual yang dibangun terdiri dari, Usecase Diagram dan Entity Relationship Diagram serta layout tampilan dari Mading Digital. 
Usecase Diagram merupakan penggambaran interaksi yang dilakukan oleh pengguna sebagai aktor dengan sistem yang dibangun[12]. Usecase Diagram pada penelitian ini terdiri dari dua yaitu Usecase Diagram dengan aktor masyarakat dan Usecase Diagram dengan aktor administror. Usecase Diagram pada masyarakat dapat dilihat pada gambar 2 .

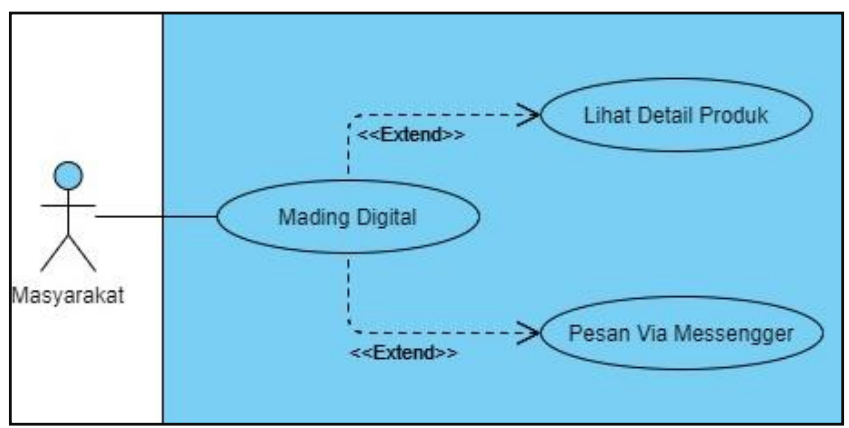

Gambar 2. Usecase Diagram Masyarakat

Masyarakat sebagai aktor dapat melihat informasi yang disajikan pada Mading Digital. Informasi yang diberikan berupa informasi event, pelaku UMKM dan galeri produk UMKM. Kemampuan lain dari Mading Digital ini adalah masyarakat dapat melihat informasi detail produk dari produk UMK yang dipilih, serta dapat melakukan pemesanan. Adapun pemesanan akan langsung terhubung dengan aplikasi messenger pemilik UMKM. Data-data yang dilihat oleh masyarakat diperoleh dari database dengan pengelolaan oleh aplikasi yang digunakan oleh administrator. Usecase Diagram untuk administrator dapat dilihat pada gambar 3.

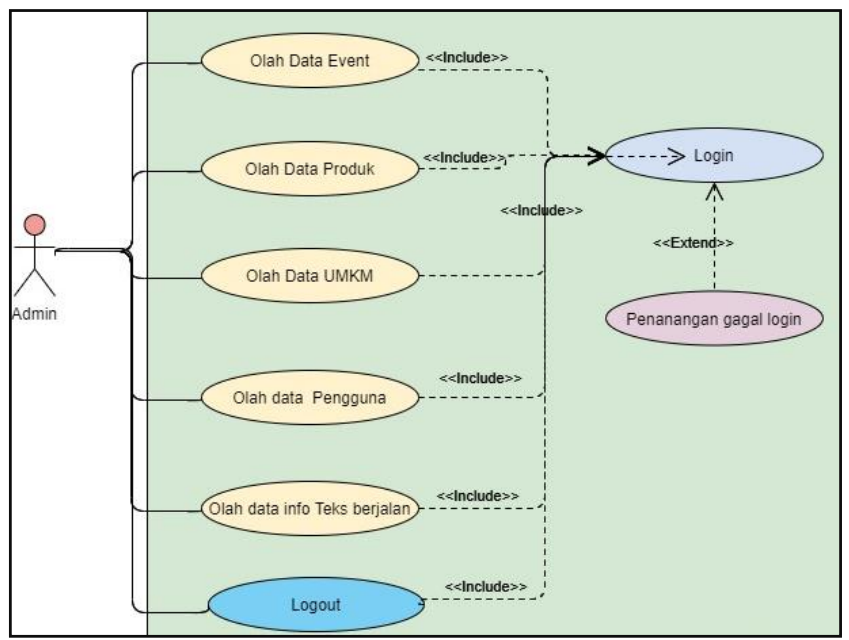

Gambar 3. Usecase Diagram Administrator

Administrator mempunyai akses untuk mengeolah data yang berkaitan dengan penyajian informasi Mading Digital. Untuk masuk ke aplikasi, admin sebagai aktor perlu melakukan proses login terlebih dahulu menggunakan username dan password yang dimilikinya. Olah data yang dilakukan meliputi proses input, update dan hapus data ke database. Aktifitas olah data terdiri dari olah data event, olah data produk, olah data pelaku, oleh data pengguna sistem, olah data info teks. Untuk memastikan keamanan pengolahan data, aplikasi dilengkapi fitur logout ketika aplikasi selesai digunakan.

Untuk melengkapi Usecase Diagram, perlu dibuat rancangan konseptual database untuk memastikan data siap diolah berdasarkan Usecase Diagram. Model konseptual database disajikan dalam bentuk kamus data dan Entity Relationship Diagram (ERD). ERD digunakan untuk menggambarkan derajat kardinalitas relasi antar tabel yang akan dibangun pada database. ERD Mading Digital dapat dilihat pada Gambar 4 sedangkan penyajian atribut datanya dalam bentuk Kamus Data yang dapat dilihat pada tabel 1 . 


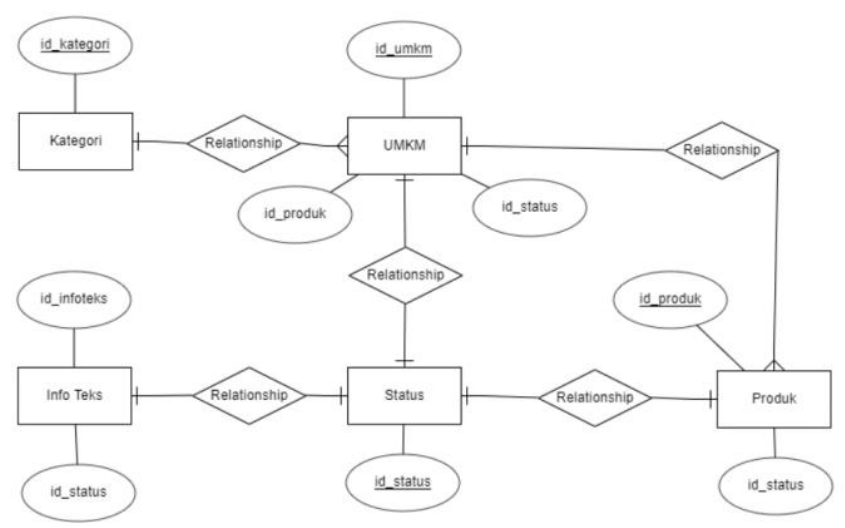

Gambar 4. ERD Mading Digital

Tabel 1. Kamus Data Mading Digital

\begin{tabular}{|l|l|l|}
\hline No & Nama Tabel & Kamus data \\
\hline 1 & Event & Id_event*, nama_event, tanggal, file \\
\hline 2 & Info teks & Id_teks*, isi_teks, id_status** \\
\hline 3 & Kategori & Id_kategori*, nama_kategori \\
\hline 4 & Produk & $\begin{array}{l}\text { Id_produk*, id_umkm***, tanggal, nama_produk, file, deskripsi, } \\
\text { harga, id_status** }\end{array}$ \\
\hline 5 & Status & Id_status*, nama_status \\
\hline 6 & UMKM & $\begin{array}{l}\text { Id_umkm*, nama_umkm, id_kategori**, file, alamat, no_telp, } \\
\text { id_status }\end{array}$ \\
\hline 7 & User & Id_user, username, password, email, nama_lengkap, alamat, level \\
\hline
\end{tabular}

Pada tahap ini juga dilakukan perancangan halaman antar muka. Informasi yang ditampilkan pada Mading Digital berupa banner event dalam bentuk gambar, pelaku UMKM berdasarkan kategorinya serta galeri produk. Informasi pelaku UMKM ditampilkan gambar/logo UMKM, nama UMKM serta tombol hubungi UMKM yang tehubung langsung ke pemilik UMKM. Informasi pada galeri produk berupa gambar produk, harga produk, pemilik produk, deskripsi produk dan tombol pesan yang akan diarahkan langsung ke pemilik UMKM. Layout Mading Digital dapat dilihat pada gambar 5.

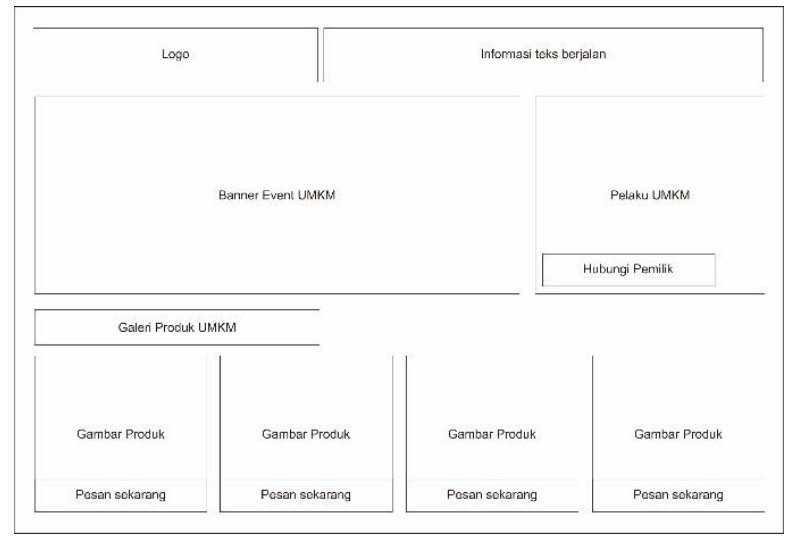

Gambr 5. Layout tampilan antar muka Mading Digital

Setelah tahap perancangan selesai, tahap selanjutnya adalah pembuatan aplikasi. Dalam metode prototyping, pada tahap ini dibuat prototipe dengan tingkat ketepatan tinggi (high fidelity prototype) dimana aplikasi sudah dibangun menggunakan bahasa pemrograman, database dan aplikasi berbasis Integrated Development Environment (IDE). Bahasa pemrograman yang digunakan adalah paket Bahasa pemrograman berbasis web yang terdiri dari PHP, HTML, CSS dan Javascript. Framework Bootstrap juga digunakan untuk 
menjaga konsistensi serta responsivitas tampilan Mading Digital. Untuk menampung data Mading Digital, database yang digunakan adalah MySql sebagai sumber data. Tampilan Mading Digital dapat dilihat pada gambar 6.

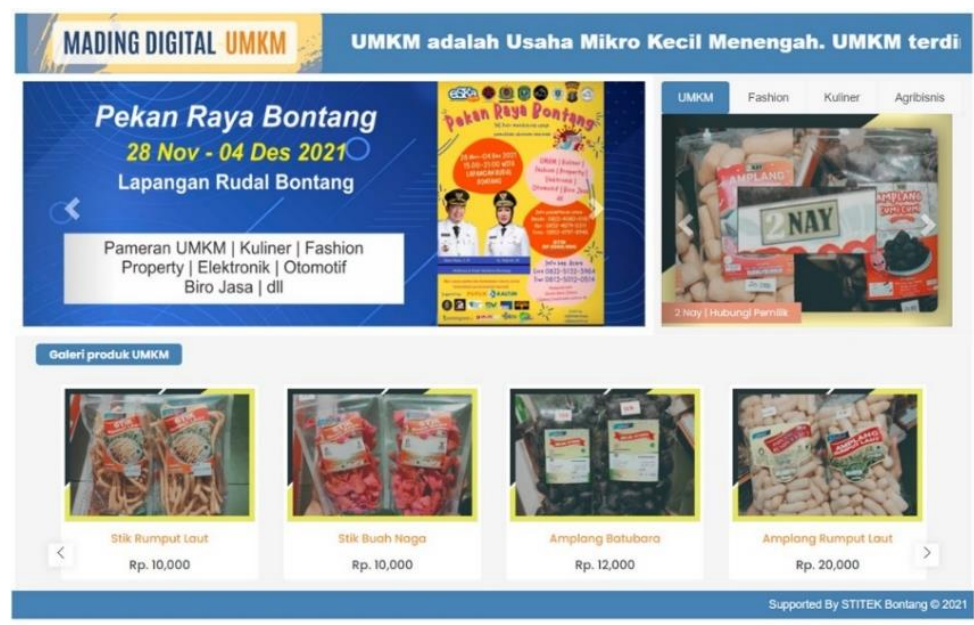

Gambar 6. Tampilan Halaman Mading Digital

Tampilan olah data yang akan digunakan oleh admin dapat dilihat pada gambar 7 dan gambar 8 .

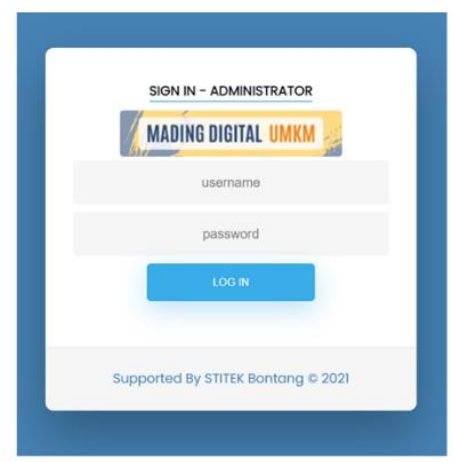

Gambar 7. Tampilan Halaman Login Administrator

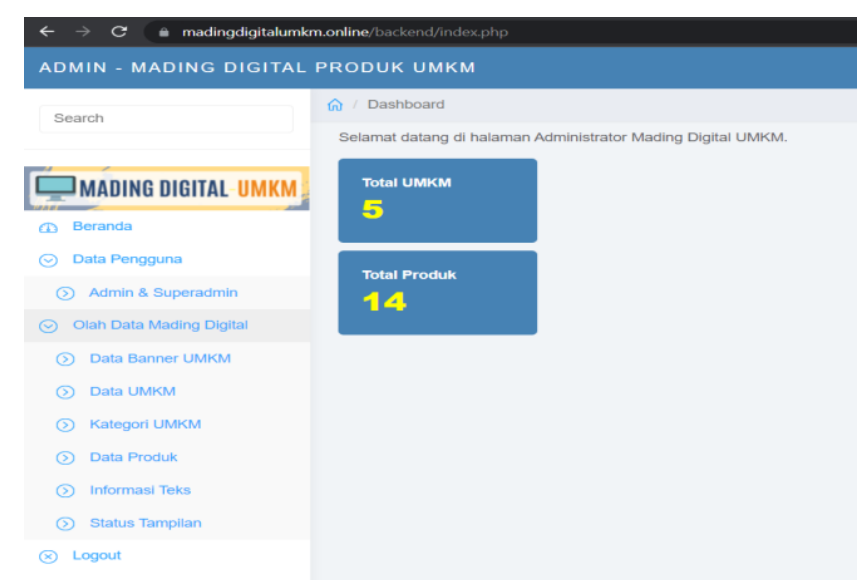

Gambar 8. Tampilan Halaman Dashboard Administrator

Setelah tahap pengembangan aplikasi selesai, tahap terakhir yang dilakukan adalah tahap pengujian. Metode pengujian yang dilakukan terhadap Mading Digital menggunakan metode blackbox. Metode blackbox dipilih karena paling dekat menggambarkan keberhasilan sistem agar sesuai dengan harapan pengguna 
akhir[13]. Jenis pengujian yang dilakukan adalah menggunakan functional testing. Hasil pengujian sistem dapat dilihat pada tabel 2.

Tabel 2. Hasil Pengujian Mading Digital

\begin{tabular}{|c|c|c|c|c|}
\hline No & Test Case & $\begin{array}{ll}\begin{array}{l}\text { Hasil yang } \\
\text { diharapkan }\end{array} & \\
\end{array}$ & Hasil yang didapatkan & Kesimpulan \\
\hline 1 & $\begin{array}{l}\text { Halaman Mading } \\
\text { Digital }\end{array}$ & $\begin{array}{lr}\text { Sistem akan } \\
\text { menampilkan } \\
\text { informasi dari } \\
\text { database sesuai } \\
\text { layout mading }\end{array}$ & $\begin{array}{l}\text { Sistem menampilkan } \\
\text { informasi banner, teks } \\
\text { berjalan, pelaku, dan } \\
\text { galeri produk sesuai } \\
\text { dengan data di database }\end{array}$ & Berhasil \\
\hline 2 & Tombol pesan & $\begin{array}{l}\text { Sistem akan masuk } \\
\text { ke redia } \\
\text { pemesanan produk }\end{array}$ & 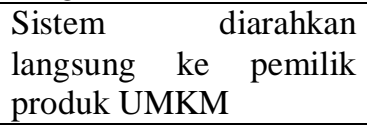 & Berhasil \\
\hline 3 & $\begin{array}{l}\text { Pengujian login } \\
\text { admin }\end{array}$ & $\begin{array}{lr}\text { Sistem akan masuk } \\
\text { ke } & \text { dashboard } \\
\text { setelah } & \text { login } \\
\text { dilakukan } & \end{array}$ & $\begin{array}{l}\text { Sistem melakukan } \\
\text { proses login sesui data } \\
\text { login yang ada pada } \\
\text { database. Jika data login } \\
\text { ada, sistem akan } \\
\text { diteruskan ke halaman } \\
\text { dashboard, jika data } \\
\text { login tidak ada sistem } \\
\text { akan memberikan info } \\
\text { login gagal dan } \\
\text { menginputkan lagi data } \\
\text { login yang baru. }\end{array}$ & Berhasil \\
\hline 4 & $\begin{array}{l}\text { Pengujian sistem } \\
\text { menu }\end{array}$ & $\begin{array}{l}\text { Sistem akan masuk } \\
\text { ke modul menu }\end{array}$ & $\begin{array}{l}\text { Sistem masuk ke } \\
\text { halaman setiap menu } \\
\text { sesuia tombo menu yang } \\
\text { dipilih. }\end{array}$ & Berhasil \\
\hline 5 & $\begin{array}{l}\text { Pengujian tampilan } \\
\text { data }\end{array}$ & $\begin{array}{l}\text { Data ditampilkan } \\
\text { sesuai modul yang } \\
\text { dipilih }\end{array}$ & $\begin{array}{l}\text { Data ditampilkan dalam } \\
\text { bentuk tabel sesuai yang } \\
\text { ada pada database. }\end{array}$ & Berhasil \\
\hline 6 & $\begin{array}{l}\text { Pengujian tambah } \\
\text { data }\end{array}$ & $\begin{array}{lr}\text { Data } & \text { akan } \\
\text { dimasukkan } & \text { sesuai } \\
\text { dengan } & \text { yang } \\
\text { dimasukkan } & \\
\text { pengguna } & \\
\end{array}$ & $\begin{array}{l}\text { Data bertambah sesuai } \\
\text { inputan pengguna }\end{array}$ & Berhasil \\
\hline 7 & $\begin{array}{l}\text { Pengujian upload } \\
\text { file }\end{array}$ & $\begin{array}{lr}\text { File } & \text { akan } \\
\text { dimasukkan } & \text { dalam } \\
\text { file server sedangan } \\
\text { deskripsi } & \text { file } \\
\text { dimasukkan } & \text { ke } \\
\text { database } & \\
\end{array}$ & $\begin{array}{l}\text { File dicopy ke server, } \\
\text { data dari gambar masuk } \\
\text { ke database }\end{array}$ & Berhasil \\
\hline 8 & Pengujian edit data & $\begin{array}{l}\text { Data akan berubah } \\
\text { sesuai dengan } \\
\text { inputan pengguna }\end{array}$ & $\begin{array}{l}\text { Data ditabase berubah } \\
\text { sesuai inputan } \\
\text { pengguna. Data lama } \\
\text { telah diganti dengan data } \\
\text { baru. }\end{array}$ & Berhasil \\
\hline 9 & $\begin{array}{l}\text { Pengujian hapus } \\
\text { data }\end{array}$ & $\begin{array}{l}\text { Data di database } \\
\text { akan hilang sesuai } \\
\text { dengan permintaan } \\
\text { hapus data oleh } \\
\text { pengguna }\end{array}$ & $\begin{array}{l}\text { Data yan gdipilih untuk } \\
\text { dihapus hilang dari } \\
\text { database. }\end{array}$ & Berhasil \\
\hline
\end{tabular}




\section{Kesimpulan}

Berdasarkan hasil pembahasan dari penelitian yang telah dilakukan, dapat diambil kesimpulan sebagai berikut.

1. Mading Digital berhasil dibuat sesuai dengan hasil perancagan dan kebutuhan sistem.

2. Mading Digital yang telah dibuat dapat digunakan oleh pelaku usaha mikro, kecil dan menengah (UMKM) sebagai media promosi produk UMKM mereka.

3. Masyarakat sebagai pengguna terbantu untuk mencari produk UMKM yang dinginkan sekaligus melakukan pemesanan langsung kepada pemilik UMKM melalui Mading Digital menggunakan perangkat yang mereka miliki seperti komputer, tablet maupun smartphone.

\section{Daftar Pustaka}

[1] A. F. Thaha, "Dampak Covid-19 Terhadap UMKM di Indonesia," J. Lentera Bisnis, vol. 2, no. 1, pp. $147-153,2020$.

[2] S. Tirtayasa, I. Nadra, and H. Khair, "Strategi Pemasaran Terhadap Peningkatan Kinerja UMKM dimoderasi Teknologi pada masa Pandemi Covid-19 The Effect of Marketing Strategy on Improving SMEsPerformance is moderated by Technology during the Covid-19 Pandemic," J. Ilm. Manaj. Dan Bisnis, vol. 22, no. 2, pp. 245-260, 2021.

[3] W. laura Hardilawati, "Strategi Bertahan UMKM di Tengah Pandemi Covid-19," J. Akunt. dan Ekon., vol. 10, no. 1, pp. 89-98, 2020.

[4] R. Pasaribu, "Optimalization of Online Media As a Solution for Msme Marketing Promotion in Semarang Through Covid-19 Pandemic," J. Komun. dan Media, vol. 01, no. 01, pp. 33-44, 2020.

[5] R. A. P. N. S. Harianto, "Strategic Digitalization of UMKM Business as an Alternative to Survive the COVID-19 Pandemic," Linguist. Cult. Rev., vol. 5, no. Agustus, pp. 617-623, 2021.

[6] S. Utomo and A. R. Naldi, "Perancangan Mading Digital Interaktif Di Fakultas Ilmu Komputer Dan Informatika Studi Kasus: Universitas Nurtanio Bandung," J. Teknol. Inf. dan Komun., vol. IX, no. 2, 2021.

[7] J. Hartono, Sistem Teknologi Informasi Edisi III. Yogyakarta: Andi, 2008.

[8] Fatansyah, Basis Data. Bandung: Informatika, 2002.

[9] M. Munawir, S. Susmanto, Z. Zulfan, and Y. Yanti, "Sistem Pelayanan Surat Administrasi Masyarakat Gampong Berbasis Webbase dengan menggunakan Framework CodeIgniter," J. Serambi Eng., vol. 5, no. $1,2020$.

[10] D. Purnomo, "Model Prototyping Pada Pengembangan Sistem Informasi," J I M P - J. Inform. Merdeka Pasuruan, vol. 2, no. 2, pp. 54-61, 2017.

[11] S. Handayani, "Perancangan Sistem Informasi Penjualan Berbasis E-Commerce Studi KaHandayani, S. (2018). Perancangan Sistem Informasi Penjualan Berbasis E-Commerce Studi Kasus Toko Kun Jakarta. ILKOM Jurnal Ilmiah, 10(2), 182-189. https://doi.org/10.33096/ilkom.v10i2.310,” Ilk. J. Ilm., vol. 10, no. 2, pp. 182-189, 2018.

[12] S. Almasik, A. R. Atmadja, and Y. Pariyatin, "Rancang Bangun Aplikasi Forum Diskusi Usaha Mikro Kecil dan Menengah Berbasis Web," J. Algoritm., vol. 17, no. 2, pp. 168-175, 2021.

[13] I. J. Efendi, "Black-Box Testing : Analisis Kualitas Aplikasi Source Code Bank Programming," J. JTIK (Jurnal Teknol. Inf. dan Komunikasi) J., vol. 5, no. 1, pp. 1-6, 2021. 